\title{
Beyond duplicity and ignorance in global fisheries*
}

\author{
DANIEL PAULY \\ Sea Around Us Project, Fisheries Centre Fisheries Centre, University of British Columbia, Vancouver, V6T 1Z4, Canada.
}

\begin{abstract}
SUMMARY: The three decades following World War II were a period of rapidly increasing fishing effort and landings, but also of spectacular collapses, particularly in small pelagic fish stocks. This is also the period in which a toxic triad of catch underreporting, ignoring scientific advice and blaming the environment emerged as standard response to ongoing fisheries collapses, which became increasingly more frequent, finally engulfing major North Atlantic fisheries. The response to the depletion of traditional fishing grounds was an expansion of North Atlantic (and generally of northern hemisphere) fisheries in three dimensions: southward, into deeper waters and into new taxa, i.e. catching and marketing species of fish and invertebrates previously spurned, and usually lower in the food web. This expansion provided many opportunities for mischief, as illustrated by the European Union's negotiated 'agreements' for access to the fish resources of Northwest Africa, China's agreement-fee exploitation of the same, and Japan blaming the resulting resource declines on the whales. Also, this expansion provided new opportunities for mislabelling seafood unfamiliar to North Americans and Europeans, and misleading consumers, thus reducing the impact of seafood guides and similar effort toward sustainability. With fisheries catches declining, aquaculture - despite all public relation efforts—not being able to pick up the slack, and rapidly increasing fuel prices, structural changes are to be expected in both the fishing industry and the scientific disciplines that study it and influence its governance. Notably, fisheries biology, now predominantly concerned with the welfare of the fishing industry, will have to be converted into fisheries conservation science, whose goal will be to resolve the toxic triad alluded to above, and thus maintain the marine biodiversity and ecosystems that provide existential services to fisheries. Similarly, fisheries economists will have to get past their obsession with privatising fisheries resources, as their stated goal of providing the proper incentives to fishers can be achieved without giving away what are, after all, public resources. Overall, the crisis that fisheries are now going through can be seen as an opportunity to renew both their structure-away from fuel-intensive largescale fisheries - and their governance, and to renew the disciplines which study fisheries, creating a fisheries conservation science in the process. Its greatest achievement will be the creation of a global network of Marine Protected Areas, which, as anticipated by Ramon Margalef, is the way to make controlled exploitation compatible with the continued existence of functioning marine ecosystems.
\end{abstract}

Keywords: conservation, overfishing, bycatch, IUU, management, quotas, historic changes.

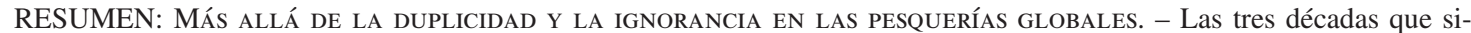
guieron a la Segunda Guerra Mundial fueron un período de rápido incremento en el esfuerzo y la captura pesquera, pero también de colapsos espectaculares, principalmente de los estocs de peces pelágicos pequeños. Durante este periodo también apareció un 'trío tóxico', según el cual, declarar capturas inferiores a las reales, ignorar las sugerencias de la comunidad científica y culpabilizar al medio ambiente constituyeron la respuesta usual a los continuos colapsos pesqueros que, por ello, se volvieron más frecuentes, y acabaron por abarcar las principales pesquerías del Atlántico Norte. La respuesta a la disminución de los caladeros de pesca tradicionales fue una expansión de las pesquerías del Atlántico Norte (y del Hemisferio Norte en general) en tres dimensiones: hacia el sur, hacia aguas más profundas y a nuevos organismos, o sea, capturando y vendiendo especies de peces e invertebrados que antes se desechaban, y que generalmente pertenecen a niveles inferiores de la red trófica. Esta expansión ofreció muchas oportunidades para realizar disparates, como los "acuerdos" negociados por la Unión Europea para acceder a los recursos pesqueros del Noroeste de África, el acuerdo-cuota que permitía a China explotar la misma región, y el que Japón culpara a las ballenas por la resultante disminución de los recursos. Además esta expansión ofreció nuevas oportunidades para etiquetar mal a las especies poco conocidas por los norteamericanos o europeos, y engañar a los consumidores, reduciendo así el impacto de las guías de consumo de pescados y otros esfuerzos similares dirigidos hacia la sostenibilidad. Con las capturas pesqueras disminuyendo, la acuicultura - a pesar de todos los esfuerzos de relaciones públicas - siendo incapaz de compensar la pérdida, y el rápido incremento de los precios de combustibles, deben 


\begin{abstract}
esperarse cambios tanto en la industria pesquera como en las disciplinas científicas que la estudian, e influyen en su gestión. En particular, la biología pesquera, ahora preocupada predominantemente por el bienestar de la industria pesquera, tendrá que convertirse a la ciencia de la conservación de las pesquerías, cuyo objetivo será el de resolver el 'trío tóxico' mencionado anteriormente, y así mantener la biodiversidad marina y de los ecosistemas que proveen servicios esenciales a las pesquerías. De manera similar, los economistas pesqueros deberán superar su obsesión por la privatización de los recursos pesqueros, dado que su objetivo declarado de proveer a los pescadores con incentivos adecuados puede ser logrado sin regalar lo que son, después de todo, recursos públicos. En términos generales, la crisis por la que están atravesando las pesquerías puede considerarse como una oportunidad para renovar su estructura - alejándose de las pesquerías a gran escala y con uso intensivo de combustible - y gestión, y renovar las disciplinas que estudian a las pesquerías, creando durante ese proceso una ciencia de conservación pesquera. Su mayor logro será la creación de una red mundial de Áreas Naturales Protegidas, lo cual, como lo anticipara Ramón Margalef, es la manera de establecer una explotación controlada, compatible con la existencia duradera del funcionamiento de los ecosistemas marinos.
\end{abstract}

Palabras clave: conservación, sobrepesca, captura incidental, INDNR, gestión, cuotas, cambios históricos.

\section{INTRODUCTION}

\section{Setting the stage}

Statistics covering the 'visible' part of global fisheries have existed since the 1930s, when the unfortunate League of Nations first attempted to report on the world's economy. The United Nations, founded in 1944, followed on this effort (Ward, 2004), with the Food and Agriculture Organisation of the United Nations (FAO) issuing the first Yearbook of Fisheries Statistics in 1950. The data in these yearbooks, annually revised and updated, are also available online (at www.fao.org) and are widely used by the FAO and other UN agencies, but also by academics and other researchers to track the development of fisheries by country and region and globally, and to pronounce on their future prospects.

However, many of these researchers are unaware of the manner in which this dataset is created, ${ }^{1}$ and of its deficiencies (notably a huge 'invisible' catch; Fig. 1), and which will have to be faced (especially because, as the phrase goes, this is "the only dataset we have") if we want to seriously address the overexploitation of marine ecosystems.

In the first few decades after World War II, the growth of sea fisheries was very rapid, whether it is measured in terms of input into the fisheries (invested capital, vessel tonnage, etc.) or output (tonnage or ex-vessel values of the landings). This period, which created the basis for the worldwide industrialisation of fisheries, was also a time when fisheries appeared to behave like any other sectors of the economy, with increased inputs leading to increasing outputs. This is the rationale behind the subsidisation of fisheries, a subject to which we will return.

1 This observation is based on experience teaching fisheries science on five continents and interacting with hundreds of colleagues, but with a bias toward developing countries.

\section{Emergence of the 'toxic triad' of fisheries}

This period is also one of massive fisheries collapses, wherein stocks that sustained entire fishing fleets, processing plants and thousands of workers and their families seemingly disappeared overnight (Radovich, 1981). The California sardine fishery is one of these, although it does live on in John Steinbeck's Cannery Row. Others, more prosaically, were rebuilt after a few years: for example, the fishery for Atlanto-Scandian herring (Beverton, 1990) and the Peruvian anchoveta fishery, whose first massive collapse occurred in 1972 (Muck, 1987). The Peruvian example best illustrates an approach already prevalent in the heyday of the California sardine fishery: blame the environment. Thus, in Peru it was El Niño that did it, never mind the fact that the actual catch in the year prior to the collapse was about 20 million tonnes (Castillo and Mendo, 1987) rather than the 12 million tonnes that were officially reported, which itself exceeded what the best experts (John Gulland, Bill Ricker, Garth Murphy) had recommended as sustainable.

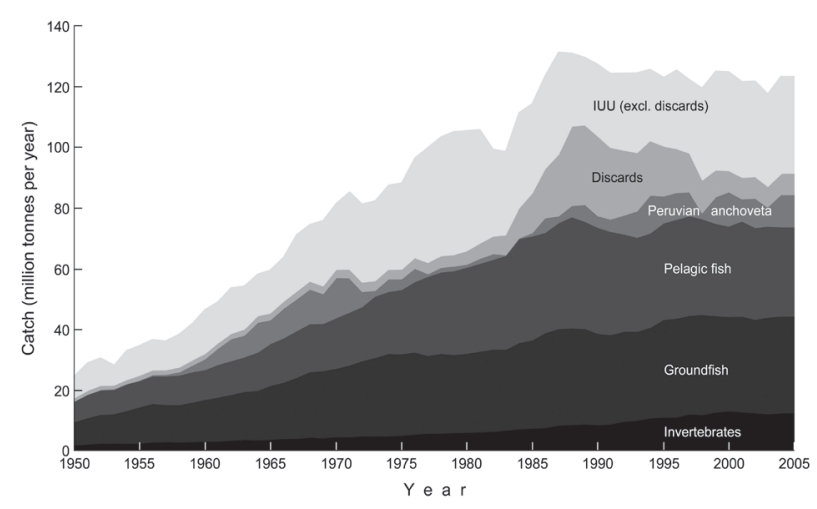

FIG. 1. - Global marine fisheries catches, 1950-2004. This graph differs from the 'official' (FAO) version of catch trend in that it accounts for $(i)$ catch over-reporting by China (Watson and Pauly, 2001); (ii) discarded by-catch (Zeller and Pauly, 2005), and (iii) catch of IUU fisheries, based on Figure 1 in Pauly et al. (2002). Note that the discards and the other catch of IUU fisheries are very tentative, but their values are certain to be considerable. 
Various concepts have been deployed to apprehend these events. One of these is the 'tragedy of the commons' (Hardin, 1968), which can be made to explain why the pathologies mentioned above were likely to occur in the largely unregulated fisheries then prevalent. The concept proposed here, of a 'toxic triad' of (1) catch underreporting, (2) overfishing (i.e. ignoring the scientific advice available at the time), and (3) blaming 'the environment' for the ensuing mess could be easily extended to cover more pathological aspects of fisheries (thus leading to a toxic tetrad, etc.), but its three elements are here sufficient for our purposes. The toxic triad existed long before its effects become widespread. However, when they did, a battery of new terms had to be coined to deal, at least conceptually, with the new development. Hence the invention of 'bycatch' by W.E. Allsopp (Pauly, 2007a), and 'IUU' (Illegal, Unreported and Unregulated fisheries) without which the stark reality they describe cannot be apprehended fully.

The toxic triad was firmly in place when, in 1975, catches peaked in the North Atlantic, before going into a slow decline continuing to the present (Pauly and Maclean, 2003). This became evident when the giant stock of northern cod off Newfoundland and Labrador collapsed, bankrupting an entire $\mathrm{Ca}-$ nadian province and setting off a frantic search for something to blame (hungry seals, cold water, etc.) other than the out-of-control fishing industry (Rose, 2008).

\section{A threefold expansion}

The toxic triad, indeed, provided a rationale for expansion, which occurred in three dimensions:

Geographic expansion: The relatively well-documented freshwater and coastal fisheries of ancient times had the capacity to induce severe decline in, and even extirpate, vulnerable species of marine mammals, fish and invertebrates, as documented by a variety of sources (Jackson et al., 2001). However, it is only since the onset of industrial fishing, using vessels powered by fossil fuel (i.e. in the 1880 s, which saw the deployment of the first steam-powered trawlers) that successive depletion of inshore stocks, followed by that of more offshore stocks, on so on, has become routine (Roberts, 2007). Thus, in the North Sea, it took only a few years for the accumulated coastal stocks of flatfish and other groups to be depleted, and for the trawlers to be forced to move on to the central North Sea, then further, all the way to Iceland (Roberts, 2007).

A southward expansion soon followed, towards the tropics (Alder and Sumaila, 2004) and through the development of industrial fishing in the nascent Third World, often through joint ventures with European (e.g. Spanish) or Japanese firms (Bonfil et al., 1998). Obviously, this expansion created new resource access conflicts and/or intensified earlier ones, and hence the protracted 'cod war' between Iceland and Britain, or the brief 'turbot war' of March 1995 between Canada and Spain. At the close of the $20^{\text {th }}$ century, the demersal resources of all large shelves of the world, all the way South to Patagonia and Antarctica, had been depleted, mainly by trawling, along with those of seamounts and oceanic plateaus (Pauly et al., 2005).

Bathymetric expansion: The second dimension of the expansion of fishing was in depth (i.e. offshore), which affected both the pelagic and the demersal realms. In the pelagic realm, the exploitation of tuna, billfishes and increasingly sharks (for their fin; Clarke et al., 2006) by longlines and similar gear has strongly modified oceanic ecosystems, which now have much reduced biomasses of large predators (Myers and Worm, 2003). This is intensified by the use of fish aggregating devices (FADs) which, starting around the Philippines (Floyd and Pauly, 1984), have spread throughout the intertropical belt and have made accessible to fisheries small tuna and other fish which could not be captured before, thus representing an additional expansion of sorts.

In the demersal realm, trawlers were deployed that can reach down to depths of several kilometres. They yield a catch increasingly dominated by slowgrowing, deep-water species with low productivity, which cannot be exploited sustainably (Pauly et al., 2003, Morato et al., 2006). Therefore, given that the high seas (the waters outside Exclusive Economic Zones, see below) are legally unprotected against such depredations, their oceanic plateaus and seamounts are subjected to intense localised fishing pressure, with subsequent collapse of the resources; the same is then repeated on the adjacent plateau or seamount. This fishing mode is no more sustainable than tropical deforestation.

The resulting changes in biomass induce, notably via altered food webs, massive changes in demersal and pelagic communities, which can be demonstrated and quantified in various ways (see e.g. Stergiou, 2002). The Marine Trophic Index (MTI; Pauly and 
Watson 2005), i.e. the mean trophic level of fish of fisheries landings, is one of the most widely used indicators for this purpose. The MTI is declining throughout the world, meaning that, increasingly, fisheries catches are based on small fish and the invertebrates at the base of the ocean's food webs (Pauly et al., 1998).

Taxonomic expansion: this refers to previously spurned taxa being caught and processed (Pauly et al., 2003; Jacquet and Pauly, 2008). This form of expansion, which intensifies the effect of the other two, is the reason why North American and European markets increasingly display unfamiliar seafood. This, on the other hand, offers many opportunities for mislabelling products and misleading consumers (Jacquet and Pauly, 2007, 2008), which is one reason for the word 'duplicity' in my title.

\section{Digression I: Exclusive Economic Zones}

In the early 1980s, the decade-long deliberations that had been triggered by various maritime countries unilaterally declaring ownership of huge swaths of their coastal waters led to the United Nations Convention on the Law of the Sea (UNCLOS). As a result of UNCLOS, all maritime countries could claim Exclusive Economic Zones of up to 200 miles, and hence (if they had the political clout) could throw out the distant water fleets that were then operating wherever they pleased. Some more powerful countries did throw out the distant water fleets which had operated along their coast, but then began subsidising the development of national fleets that soon became as destructive as the foreign fleets had been. In the US, and Canada, this eventually led to the collapse of cod in New England and the Canadian Maritimes. Others, notably several countries in Northwest Africa, tried to throw out 'their' distant water fleets. However, without political clout, they were susceptible to blackmail (in cases their negotiators were honest) or bribery (in the other case), the result being that European and East Asian distant water fleets are still operating in that region (Kaczyinski and Fluharty, 2002).

The continued presence of distant water fleet from countries of the European Union is based on access 'agreements' of which each is a triumph of raw political power over the rhetoric of partnership and development aid-another realm in which duplicity reigns supreme. As for distant water fleets from East Asia, the rhetoric is different. China, indeed, has no rhetorical stance: its fisheries operate on what appear to be private agreements with local politicians that stay under everybody's radar screen, showing up in the press only where its trawlers get into conflicts with local fishers. This is a far cry from the situation of just a few years ago, when China was over-reporting its catches (see below).

Japan, on the other hand, manages to add insult to injury: its fisheries experts and embassies in Northwest Africa (and elsewhere, notably in the Caribbean and the South Pacific) argue that it is the whales that are responsible for the decline of the stocks, and hence that the countries in question should help re-establish 'ecosystem balance' by, among other things, voting at the International Whaling Commission in support of Japan killing more whales (see e.g. Komatsu and Misaki, 2003). This line of argument, which would be specious anywhere, ${ }^{2}$ is particularly duplicitous in Northwest Africa, where distant water fleets and overgrown 'small-scale' fisheries have been unequivocally shown to be the cause of widespread stock declines (see contributions in Chavance et al., 2004), and where baleen whales occur mainly during the reproductive season, when they do not feed. Strangely enough, and this refers to the ignorance in my title, this line of argument works in that, probably with the help of other, more practical enticements, it has re-directed the scarce research resources of several Northwest African countries toward conducting costly 'whale surveys'- this in a region that does not have observers on board the vessels of distant water fleets, and in fact, no practical way of even estimating their catches (Pauly, 2008a).

\section{THE CRISIS OF FISHERIES}

\section{Direct and indirect drivers}

The expansion trends established in the 1980s and 1990s have led to the crisis at the onset of the $21^{\text {st }}$ century, of which the following are major elements.

There is, in the global fisheries sector, a huge overcapacity (i.e. excess fishing vessels), variously estimated as two to three times that required to generate present catches (Mace, 1997; Pauly et al., 2002). This

\footnotetext{
2 Interestingly, in spite of the presence of numerous cetaceans in Japanese waters, this argument was not used by Komatsu-san at a conference held at the United Nation University on October 17, 2008 , when he turned his attention to the sorry state of Japanese coastal fisheries. Clearly, he felt he had to be serious.
} 
is probably an underestimate, given the increase in the efficiency of vessels in locating and catching fish of about $4-5 \%$ per year across a wide range of vessel types, which implies a doubling of effective fishing effort in about 15 years (Gelchu and Pauly, 2007).

The biomass of traditionally targeted large fish (cod and other demersal fish, tuna and other large pelagics) has been reduced by at least one order of magnitude since the onset of industrial exploitation (Myers and Worm, 2003; Christensen et al., 2003; Roberts, 2007). The generality of these findings has been contested (see below), but they can be straightforwardly reproduced by anyone willing to reconstruct population sizes prior to industrial exploitation, as done, e.g., for New England cod by Rosenberg et al. (2005). Without such reconstruction, arguments about depletion will be essentially useless, as subjective perceptions of abundance are biased by shifting baselines (Pauly, 1995), a bias empirically shown to be extremely strong (Sáenz-Arroyo, 2005).

One aspect of global fisheries, but one often not perceived as the scandal it is, is that about one third of the world catch of fisheries-sardines, anchovies, mackerel and other small pelagic fishes-is wasted as animal feed (mainly as fishmeal, of which about half is consumed by aquaculture), although it could easily be converted to human food (see contributions in Alder and Pauly, 2006, and Alder et al., 2008). As such, it would contribute far more to human nutrition (including to the supply of omega 3 fatty acids) than through aquaculture (which inserts a trophic step between these fish and humans), while avoiding the bioaccumulation of persistent organic pollutants which makes farmed carnivores such as salmon so problematic (Hites et al., 2004).

Note also that as the supply of small pelagics is not expected to increase in the future, the expansion of aquaculture is also going to be limited, at least if aquaculture is conceived as raising of carnivorous fish (salmon, seabass and tuna), as is usually implied in western countries (two-thirds of aquaculture production occurs in China, where the major species farmed are herbivorous freshwater fish and marine bivalves, neither of which require fishmeal). For example, the expansion of farming of high trophic level fish in the Mediterranean, i.e. 'farming up' (Stergiou et al., 2009), contrast with the 'fishing down' occurring there, as elsewhere in the world (Pauly et al., 1998). Thus, large quantities of small pelagics are fished to feed relatively few farmed fish (mainly tuna), leaving no food for marine mammals (Bearzi et al., 2006) and less fish for people who cannot afford to eat bluefin tuna sushi.

Over $50 \%$ of the fish caught in the world is traded internationally, and many industrialised countries either have huge distant water fleets (as Spain still does) and/or purchase most of the fish they consume (as Germany and Japan do). In any case, there is a large net flow of fish from developing to industrialised countries, with serious consequences for the food security of the protein-deficient, least developed countries (Kent, 2003; Alder and Sumaila, 2004).

Various market-based initiatives in industrialised countries are based on the belief that by changing consumer behaviour they can change the way fish stocks are exploited (Jacquet and Pauly, 2007, 2008). The UK-based Marine Stewardship Council (MSC) is the best known of these, along with the multitude of seafood guides which, as their name implies, are meant to advise consumers as to the 'sustainability' of the species offered, for example in restaurants (see www.seafoodguide.org). However, even if this goal was reached, it would still not solve the food security problem caused by the transfer of fish from developing to industrialised countries.

On top of it all, government subsidies to fisheries-the grease that keeps the whole creaky system going-were recently re-estimated as \$30-34 billion per year, up from the previously accepted figure of $\$ 20$ billion per year (Milazzo, 1998). Of \$30-34 billion, about 20 are 'bad' subsidies, because they enhance fish catching capacity (see contributions in Sumaila and Pauly, 2006). This applies especially to fuel subsidies, which allow profitable exploitation of depleted stocks, and thus directly contribute to the problems alluded to above. However, this could also be hint at a solution, as most industrialised fisheries, and particularly the fuel-intensive trawl fisheries, now depend on subsidies, especially fuel subsidies, which make them extremely sensitive to the increasing cost of fuel (Pauly et al., 2003). This will be enhanced by the fallout out of the bank collapses in the fall of 2008, and the eventual outcome of negotiations of the World Trade Organisation, which intends to abolish subsidies because they distort markets (Sumaila and Pauly, 2007; Sumaila et al., 2008).

\section{Subjective factors and masking effects}

In addition to the objective factors or drivers mentioned above, there are a number of subjective 
elements, some bordering on duplicity (and some crossing that border), that contribute to the crisis being masked, or at least misapprehended, and thereby contribute to the decline of marine biodiversity and ecosystem overexploitation.

The first of these factors was the massive overreporting of catches by China through the 1990s, which misled the FAO and the world into believing that global landings were increasing, while in fact, they were slowly decreasing (Watson and Pauly, 2001). This occurred because an independent statistical system does not exist in China, i.e. favourable production statistics can be manufactured by a mid-level official seeking advancement, including in the fisheries sector (Pang and Pauly, 2001). We note in passing that the FAO, which now presents world fisheries statistics with and without China, now also has slight doubts about Chinese aquaculture statistics as well (www.fao.org).

Another masking factor is that the per capita consumption in industrialised countries, especially in the EU and US, is still increasing. This implies, given a stagnating or declining global catch, that per capita consumption in developing countries (excluding China) should decline. Reliable data on fish consumption in developing countries do not exist to test this (which will be convenient to some). In the meantime, consumers in the EU and the USA are left to enjoy frissons of guilt when ordering seafood not sanctioned by their many seafood guides (see above).

However, the most potent masking factors, because they provide governments with the excuses they need not to intervene and counter negative trends, are, as in the case of global warming, the denials of self-styled 'sceptics', and their misuse of 'uncertainty'. The sceptics are effective because science needs scepticism and must recognise uncertainty, fisheries science being no exception.

Ludwig et al. (1993), in a brilliant paper now repudiated by its second co-author, outlined how scientific uncertainty is being used in fisheries to hold off intervention until it is too late to prevent stock collapses, i.e. it is not used in a precautionary fashion. This problem can be aggravated when, additionally, the sceptics combine their denials with innuendos on the objectivity and ethics of conservation-orientated scientists, the journals that publish their research and the donors that fund it-as done by Lomborg (2001) for the environment as a whole, or by Hilborn (2006) in the case of fisheries.

\section{Digression II: the underreporting of fisheries catches}

Except for China, whose political system encourages over-reporting of domestic catches, and a few instances of strongmen insisting on increasing catches in the countries they thought they controlled (e.g. Ferdinand Marcos in the Philippines in the early 1980s), the catch data available to the public and most scientists are biased downward, and against small-scale fisheries. This occurs in two steps: (1) government scientists generally study and the statistical system they set up usually monitors only commercial fisheries (and not recreational and small-scale, artisanal or subsistence fisheries, even if they collectively land the bulk of the national catch (Pauly, 2006); (2) the national agencies that report national catches to the FAO, which compiles and maintains the only global database of fisheries statistics, are usually not the departments of fisheries or similar entities, but the ministries of agriculture, or finance, or their statistical offices, which also tend to emphasise 'cash crops', i.e. exportable products such as shrimps and tuna, while giving short thrift to - and at worst completely ignoring - small-scale fisheries catches, even though it is these catches which feed their rural populations (see e.g. Jacquet and Zeller, 2007 and other contribution in Zeller and Pauly, 2007).

These two problems are so widespread that the Sea Around Us Project (Pauly, 2007b) has initiated a systematic reconstruction of the real catch (i.e. including those of IUU fisheries) of all maritime countries of the world, which is expected to be completed in 2010 .

\section{THE GLOBAL FISHERIES CRISIS AS AN OPPORTUNITY FOR RENEWAL}

\section{The renewal of fisheries science}

Clearly, we now have a situation in which a substantial fraction of the fishing industry is willing to sacrifice the future of fisheries, a future that can be sustainable only if the underlying resources are allowed to recover, and to rebuild their biomass. The most important task for a renewal of fisheries and fisheries research will therefore be the reduction of overall fishing effort. Without this, nothing else will work. Ecosystem-based considerations will also play 
a part (Pikitch et al., 2004; Cury et al., 2008). This implies ensuring, among other things, that we do not attempt to maximise catches from both predators and their food organisms. Here, no-take marine reserves will have to be perceived not as scattered and small concessions to conservationist pressure, but as a legitimate and obvious management tool designed to re-establish natural refuges lost to the geographic and bathymetric expansions described above (Pauly et al., 2003).

Indeed, avoiding the extinction of species previously protected by their inaccessibility to fishing gear should become a major goal for future management regimes. This would link fisheries scientists with the vibrant communities of researchers now working on marine biodiversity and conservation issues. Such linking, however, is not easily brought about, as suggested in the following paragraphs.

\section{Changes for which the time had come}

One of the few good things about getting old is that one develops a fine-grained appreciation of the various forms of change. One such form is the insidious gradual shifting of our baseline, which affects so much of our perception of the state of biodiversity (Pauly, 1995). Another type of change is that which occurs when insights pile up in society, but are not released before some abrupt event or 'tipping point' (Gladwell, 2000). Examples of such events that I was able to be (a very small) part of are the May 1968 Parisian revolt against an increasingly autocratic Charles de Gaulle, and the 1986 Peoples' Power revolution in Manila against the dictator Ferdinand Marcos.

Other such changes were the civil rights movement in the USA, of which I saw only the tail end and which heralded the emergence of a new mindset that could no longer comprehend how the old one was ever acceptable.

Change also occurred in my chosen profession, fisheries science. When I was a student, I was taught that the work I was learning to do was supposed to be used by fisheries managers who would ensure that the fisheries were optimised and put on some rational footing so that society would benefit. I worked first in developing countries, many of them with mighty fisheries, but the fisheries scientists that I interacted with, and for whom I adapted some of the classical stock assessment models for use in the tropics, were in no way connected to those making decisions about fisheries. Specifically, they had no connection to the heads of fishing enterprises (often called 'fishermen') and the financiers of fishing ventures, not to speak of the politicians who facilitate and subsidise these projects. In other words, these fisheries scientists had no way of effectuating change based on scientific evidence.

Later, when examining fisheries in Europe and in North America, and on a global basis, I found that this lack of access was the rule and that well-managed fisheries were the exception. I could also see the damage that fisheries do to marine ecosystems and biodiversity and that my discipline, fishery biology, did not have the conceptual apparatus for dealing with biodiversity-related issues. In fact, they were not considered legitimate research issues. Therefore, at several forums, notably the ICES annual meeting in 2000 and the $4^{\text {th }}$ World Fisheries Congress in Vancouver, at both of which I was the keynote speaker, I tried to argue from within the fisheries profession for the need to extend our discipline from one implicitly interested in keeping fishing fleets operating to a broader one devoted to maintaining the ecosystem and the resources embedded therein, upon which the fisheries ultimately depend. I did this because I considered legitimate the argument made by ecologists who viewed ecosystems as more than larders from which we extract what we want, without accounting for the externalities of fishing (Fig. 2).

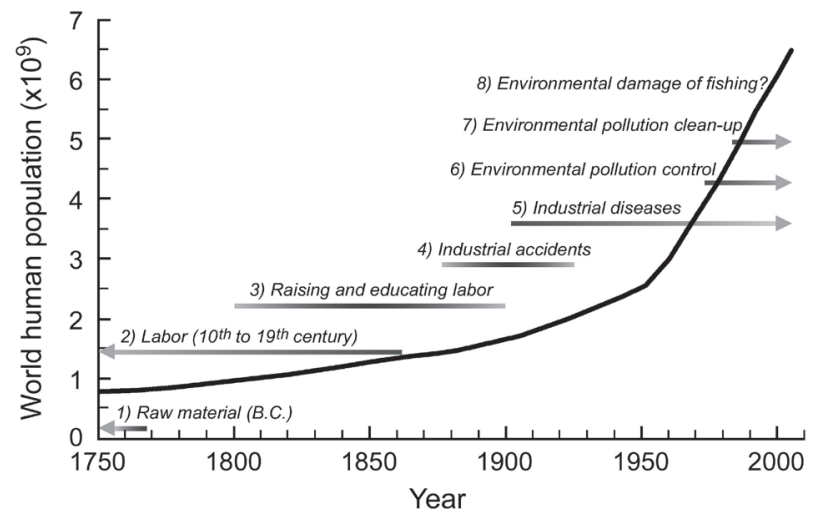

FIG. 2. - Internalisation of so-called 'external costs' in the history of Western countries (adapted with modifications from Table 4, p. 81 in Hardin, 1972, with human population growth superimposed): (1) raw materials, internalised well before the Common Era (C.E.); (2) labour, with invention of the horse collar in 1000 C.E., leading to a decline of slavery, finally abolished in 1863 C.E.; (3) beginning and spread of free public education; (4) industrial accidents: development of probability theory and of insurance schemes; (5) industrial diseases: pollution control, culminating in the U.S. Clean Air Acts of 1963 and 1970, and the Clean Water Act of 1977; (6) the Montreal Protocol on Substances That Deplete the Ozone Layer in 1989; (7) the U.S. Superfund Programme (1980) to clean up previously uncontrolled hazardous waste sites; and (8) environmental damage due to fisheries, which is still to be internalised. 
For a while I believed that these efforts, paralleled by those of numerous other colleagues, notably Jackson et al. (2001), and the late Ransom A. Myers and co-workers, would be successful in generating a new consensus. Who can argue against the need to maintain the fish that maintain the fishery? Now, with the publication of a contrarian article on "faithbased fisheries' by Hilborn (2006) and its apparently positive reception by a number of my colleagues, I see that this is not obvious at all.

Instead, what has emerged in our discipline is a discussion about standards of evidence, and indeed about what constitutes evidence. Such 'metadiscussion', i.e. discussion about the ways we ought to conduct ourselves, is indicative of a deep malaise, and of fundamental changes having occurred in our discipline, where two schools now fight for supremacy, i.e. to represent the discipline as a whole.

One school centres on the profitability of fishing enterprises and on fishing 'rights' (see below), the other on marine ecosystems and their ability to generate services, including fisheries catches. And between them, name calling has become the fashion in a way that would have been impossible in the times of Ray Beverton and, I presume, the other gentlemen (yes, they were all men) who founded quantitative fishery science.

I am not the neutral observer in this, far from it, but I think it is obvious that the next generations will expect fisheries to perform well in not only operational and financial terms, but also in ecological terms. This will involve overcoming the results of the conceptual sleight of the hand by a number of fisheries economists, in which the need of fishers to have a predictable access to the resources (Costello et al., 2008) has been turned into claims that these resources should be handed over to them in perpetuity, along with the exclusive 'rights', the resulting privatisation of a public good being called 'rights-based fishing' (Pauly, 2008b).

In most countries, the fisheries resources in the EEZs belong to the state (i.e. to us all), and these resources could be managed in the same manner as public forests or rangelands, through leases or temporary licenses which can be auctioned (Macinko and Bromley, 2002, 2004). This would help address the overcapacity problem as efficiently as through 'rights-based fishing', while avoiding the privatisation of a public good, of which we should be weary given the experience of the last decades, culminating in a financial crisis largely caused by the unmooring of the market from all ethical constraints.

\section{CONCLUSIONS}

There are basically two alternatives for fisheries science and management: one is obviously continuing with business as usual, i.e. accommodating subsidy-driven overcapacity without bothering about externalities (Fig. 2). This would lead, in addition to further depletion of biodiversity, to intensification of 'fishing down marine food web', which ultimately involves the transformation of marine ecosystems into dead zones (Pauly et al., 2009). The other alternative is to convert fisheries science and management into life-affirming disciplines, which, rather than maximising return to fisheries, would be devoted to implementing some form of more balanced, ecosystembased fisheries management, requiring consideration of more stakeholders than the fishing industry alone. This transformation would also require extensive use of ocean zoning and spatial closures, including no-take marine protected areas (MPAs).

Indeed, MPAs must be at the core of any scheme intending to put fisheries on an ecologically sustainable basis. They presently cover a cumulative area of only $0.7 \%$ of the world's oceans, and the annual increase of this area-about 5\%-is not high enough for various internationally agreed targets to be reached, e.g. $10 \%$ coverage in 2010 , as agreed by the Parties of the Convention for Biological Diversity (Wood et al., 2008).

Thus, if marine biodiversity is to be maintained and functional ecosystems re-established where uncontrolled exploitation has obliterated them, then we will have to set up larger MPAs, at a faster pace, as is also advocated by most marine ecologists, and by all non-governmental organisations working on the marine environment.

It is comforting that this thought was anticipated by Ramon Margalef (1968, p. 50) long before it became fashionable: "Probably the best solution would be a balanced mosaic or rather a honeycomb, of exploited and protected areas. Conservation is also important from the practical point of view: lost genotypes are irretrievable treasures, and natural ecosystems are necessary as references in the study of exploited ecosystems."

\section{ACKNOWLEDGMENTS}

I thank the Honourable Mr. José Montilla, President of the Generalitat of Catalonia (Spain), and the 
Management and Jury of the Ramon Margalef Prize for the opportunity to prepare this contribution which, although concerned mainly with fisheries management, also deals with the aquatic ecosystems. Ramon Margalef studied mainly the lower trophic levels of ecosystems; with this account, covering mainly their upper trophic level, we have them covered, as the phrase goes, from 'end to end'.

My gratitude also goes to Drs. Marta Coll, Isabel Palomera, John Celecia and Ms. Teresa Sala Rovira, who all contributed to my sojourn in Catalonia, and Dr. M.P. Olivar for inviting this contribution. Finally, I thank the Pew Charitable Trusts, Philadelphia, and in particular Dr. J. Reichert, for steady support of the Sea Around Us Project, in the course of which many of the ideas presented here were developed.

\section{REFERENCES}

Alder, J., B. Campbell, V. Karpouzi, K. Kaschner and D. Pauly. - 2008. Forage fish: from Ecosystems to Markets. Ann. Rev. Envir. Res., 33: 153-166.

Alder, J. and D. Pauly (eds.). - 2006. On the multiple Uses of Forage Fish: from Ecosystem to Markets. Fish. Centre Res. Rep. 14(3): 1-109.

Alder, J. and U.R. Sumaila. - 2004. Western Africa: a fish basket of Europe past and present. J. Env. Dev., 13: 156-178.

Bearzi, G.E. Politi, S. Agazzi and A. Azzelino. - 2006. Prey depletion caused by overfishing and the decline of marine megafauna in eastern Ionian Sea coastal waters (central Mediterranean). Biol. Conserv., 127: 373-382

Beverton, R.J.H. 1990. Small pelagic fish and the threat of fishing: are they threatened? J. Fish Biol., (Suppl. A): 5-16.

Bonfil R, G. Munro, U.R. Sumaila, H. Valtysson, M. Wright, T.J.M, Pitcher, D. Preikshot, N. Haggan and D. Pauly. - 1998. Impacts of distant water fleets: an ecological, economic and social assessment. In: The footprint of distant water fleet on world fisheries. Endangered Seas Campaign, pp. 11-111, WWF International, Godalming, Surrey:

Castillo, S. and J. Mendo 1987. - Estimation of unregistered Peruvian anchoveta (Engraulis ringens) in official catch statistics, 1951 to 1982. In: D. Pauly and I. Tsukayama (eds.), The Peruvian anchoveta and its upwelling ecosystem: three decades of changes, pp. 109-116. ICLARM Studies and Reviews 15.

Chavance, P., M. Ba, D. Gascuel, M. Vakily and D. Pauly (eds.). - 2004. Pêcheries maritimes, écosystèmes et sociétés en Afrique de l'Ouest: un demi-siècle de changement. Actes du symposium international, Dakar - Sénégal, 24-28 juin 2002. Office des publications officielles des communautés Européennes, XXXVI, collection des rapports de recherche halieutique ACPUE $15,532 \mathrm{pp}$

Christensen V., S. Guénette, J.J. Heymans, C.J. Walters, R. Watson, D. Zeller and D. Pauly. - 2003. Hundred year decline of North Atlantic predatory fishes. Fish Fish., 4: 1-24

Clarke, S.C., M.K. McAllister, E.J. Milner-Gulland, G.P. Kirkwood, C.G.J. Michielsens, D.J. Agnew, E.D. Pikitch, H. Nakano and M.S. Shivji. - 2006. Global estimates of shark catches using trade records from commercial markets. Ecol. Lett., 9: $1115-1126$.

Costello, C., S.D. Gaines and J. Lynham. - 2008. Can catch shares prevent fisheries collapses? Science, 321: 1678-1681.

Cury, P.M., Y.-J Shin, B. Planque, J.M. Durant, J.-M. Fromentin, S. Kramer-Schadt, N.C Stenseth, M. Travers, and V. Grimm. - 2008. Ecosystem oceanography for global change in fisheries. Trends Ecol. Evol., 23: 338-346.

Floyd, J. and D. Pauly. - 1984. Smaller size tuna around the Philip- pines - can fish aggregating devices be blamed? Infofish Marketing Digest 5/84: 25-27.

Gelchu, A. and D. Pauly. 2007. Growth and distribution of portbased fishing effort within countries' EEZ from 1970 to 1995. Fish. Centre Res. Rep., 15(4): 1-99.

Gladwell, M. - 2000. The Tipping Point: How Little Things Can Make a Big Difference. Little, Brown and Company, New York.

Hardin, G. - 1968. The tragedy of the commons. Science, 162; $1243-1248$

Hardin, G. - 1972. Exploring new ethics for survival: the voyage for the spaceship Beagle. The Viking Press, New York.

Hilborn, R. - 2006. Faith-based fisheries. Fisheries, 31: 554-555.

Hites, R.A., J.A. Foran, D.O. Carpenter, M.C. Hamilton, B.A. Knuth and S.J. Schwager. - 2004. Global assessment of organic contaminants in farmed salmon. Science, 303: 225-229.

Jackson, J.B.C., M.X. Kirby, W.H. Berger, K.A. Bjorndal, L.W. Botsford, B.J. Bourque, R. Cooke, J.A. Estes, T.P. Hughes, S. Kidwell, C.B. Lange, H.S. Lenihan, J.M. Pandolfi, C.H. Peterson, R.S. Steneck, M.J. Tegner and R.R. Warner. - 2001. Historical overfishing and the recent collapse of coastal ecosystems. Science, 293: 629-638.

Jacquet, J. and D. Pauly. - 2007. The Rise of Seafood Awareness Campaigns in an Era of Collapsing Fisheries. Mar. Policy, 31: 308-313.

Jacquet J, and D. Pauly. - 2008. Trade secrets: renaming and mislabeling of seafood. Mar. Policy 32: 309-318.

Jacquet, J. and D. Zeller. - 2007. National conflict and fisheries: reconstructing marine fisheries catches for Mozambique. In: D. Zeller and D. Pauly (eds.). Reconstruction of Marine Fisheries Catches for Key Countries and Regions (1950-2005). Fish. Centre Res. Rep., 15(2): 35-47

Kaczyinski, V.M. and D.L. Fluharty. - 2002. European policies in West Africa: who benefits from fisheries agreements? Mar. Policy, 26: 75-93.

Kent, G. - 2003. Fish trade, food security, and the human right to adequate food. In: Report of the expert consultation on international fish trade and food security. Casablanca, Morocco, 27-30 January 2003, Rome. FAO Fish. Rep., 708: 49-70.

Komatsu, M. and S. Misaki. - 2003. Whales and the Japanese: how we have come to live in harmony with the bounty of the sea. The Institute of Cetacean Research, Tokyo.

Lomborg, B. - 2001. The skeptical environmentalist: measuring the real state of the world. Cambridge University Press, Cambridge.

Ludwig, D., R. Hilborn, C. Walters. - 1993. Uncertainty, resource exploitation and conservation: lessons from history. Science, 260: 17 and 36

Mace, P.M. - 1997. Developing and sustaining world fisheries resources: the state of science and management. In: D.H. Hancock, D.C. Smith, A. Grant and J.P. Beumer (eds.), Developing and sustaining world fisheries resources: the state of science and management, pp. 1-20. Proc. Second World Fish. Congress, Brisbane, Australia. CSIRO Publishing, Australia.

Macinko, S. and D.W. Bromley. - 2002. Who Owns America's Fisheries? Island Press, Washington, D.C.

Macinko, S. and D.W. Bromley. - 2004. Property and Fisheries for the Twenty-First Century: Seeking Coherence from Legal and Economic Doctrine. Vermont Law Rev., 28:623-61.

Margalef, R. - 1968. Perspectives in Ecological Theory. University of Chicago Press. Chicago.

Milazzo, M. - 1998. Subsidies in World Fisheries: A Re-examination. World Bank Tech. Pap., 406: 1-87.

Morato, T, R. Watson, T.J. Pitcher and D. Pauly. - 2006. Fishing down the deep. Fish Fish., 7: 24-34.

Muck, P. - 1989. Major trends in the pelagic ecosystem off Peru and their implications for management. In: D. Pauly, P. Muck, J. Mendo, and I. Tsukayama (eds.). The Peruvian upwelling ecosystem: dynamics and interactions. ICLARM Conf. Proc. Manila, 18: 386-403.

Myers, R.A. and B. Worm. - 2003. Rapid worldwide depletion of predatory fish communities. Nature, 423: 280-283.

Pang L. and D. Pauly. - 2001. Chinese marine capture fisheries from 1950 to the late 1990s: the hopes, the plans and the data. In: R. Watson, L. Pang and D. Pauly (eds.). The marine fisheries of China: development and reported catches. Fish. Centre Res. Rep., 9(2): 1-27.

Pauly, D. - 1995. Anecdotes and the shifting baseline syndrome of 
fisheries. Trends Ecol. Evol., 10(10): 430.

Pauly, D. - 2006. Major trends in small-scale marine fisheries, with emphasis on developing countries, and some implications for the social sciences. Marit. Stud. (MAST), 4(2): 7-22.

Pauly, D. - 2007a. On bycatch, or how W.H.L. Allsopp coined a new word and created new insights. Sea Around Us Proj. Newsl., November/December 2007, (44): 1-4.

Pauly, D. - 2007b. The Sea Around Us Project: Documenting and Communicating Global Fisheries Impacts on Marine Ecosystems. AMBIO: J. Hum. Environ., 34(4): 290-295.

Pauly, D. - 2008a. Worrying about whales instead of managing fishing: a personal account of a meeting in Senegal. Sea Around Us Proj. Newsl., May/June 2008, (47): 1-4.

Pauly, D. - 2008b. Agreeing with Daniel Bromley. Marit. Stud. (MAST), 6(2): 27-28

Pauly, D. and J. Maclean. - 2003. In a Perfect Ocean: fisheries and ecosystem in the North Atlantic. Island Press, Washington, D.C.

Pauly, D. and R. Watson. - 2005. Background and interpretation of the 'Marine Trophic Index' as a measure of biodiversity. Philos. Trans. R. Soc.: Biol. Sci., 360: 415-423.

Pauly, D., V. Christensen, J. Dalsgaard, R. Froese, and F.C. Torres Jr. - 1998. Fishing down marine food webs. Science, 279: 860-863.

Pauly, D., V. Christensen, S. Guénette, T.J. Pitcher, U.R. Sumaila, C.J. Walters, R. Watson and D. Zeller. - 2002. Towards sustainability in world fisheries. Nature, 418: 689-695.

Pauly, D., J. Alder, E. Bennett, V. Christensen, P. Tyedmers and R. Watson. - 2003. The future for fisheries. Science, 302: 1359-1361.

Pauly, D., J. Alder, A. Bakun, S. Heileman, K.H. S, Kock, P. Mace, W. Perrin, K.I. Stergiou, U.R. Sumaila, M. Vierros, K.M.F. Freire, Y. Sadovy, V. Christensen, K. Kaschner, M.L.D. Palomares, P. Tyedmers, C. Wabnitz, R. Watson, and B. Worm. - 2005. Marine Systems. In: R. Hassan, R. Scholes, N. Ash (eds.), Ecosystems and Human Well-being: Current States and Trends, vol. 1. pp. 577-511. Millennium Ecosystem Assessment and Island Press, Washington, D.C.

Pauly, D., W. Graham, S. Libralato, L. Morissette and M.L.D. Palomares. - 2009. Jellyfish in ecosystems, online databases and ecosystem models. Hydrobiologia, 616(1): 67-85.

Pikitch, E.K., C. Santora, E.A. Babcock, A. Bakun, R. Bonfil, D.O. Conover, P. Dayton, P. Doukakis, D. Fluharty, B. Heneman, H.D. Houde, J. Link, P.A. Livingston, M. Mangel, M.K. McAllister, J. Pope and K.J. Sainsbury. - 2004. Ecosystem-Based Fishery Management. Science, 305: 346-347.

Radovich, J. - 1981. The collapse of the California sardine industry: what have we learned? In: M.H. Glantz and D. Thomson (eds.), pp. 107-136. Resource Management and Environmental Uncertainty. Wiley, New York.

Roberts, C. - 2007. The Unnatural History of the Sea. Island Press, Washington D.C.

Rose, A. - 2008. Who killed the Grand Banks: the untold story behind the decimation of one of the world's greatest natural resource. John Wiley and Sons.

Rosenberg, A.A., W.J. Bolster, K.E. Alexander, W.B. Leavenworth, A.B. Cooper and M.G. McKenzie. -2005 . The history of ocean resources: modeling cod biomass using historical records. Front. Ecol. Evol., 3(2): 84-90.

Sáenz-Arroyo, A., C.M. Roberts, J. Torre, M. Cariño-Olvera and R. Enríquez-Andrade. - 2005. Rapidly shifting environmental baselines among fishers of the Gulf of California. Proc. R. Soc. B., 272: 1957-1962.

Stergiou, K.I. - 2002. Overfishing, tropicalization of fish stocks, uncertainty and ecosystem management: resharpening Ockham's razor. Fish. Res., 55: 1-9.

Stergiou, K.I., A.C. Tsikliras and D. Pauly. - 2009. Farming up the Mediterranean food webs. Conserv. Biol., 23(1): 230-232.

Sumaila, U.R. and D. Pauly (eds.). - 2006. Catching more bait: a bottom-up re-estimation of global fisheries subsidies. Fish Centre Res. Rep., 14(6):1- 114.

Sumaila, U.R. and D. Pauly. - 2007. All fishing nations must unite to cut subsidies. Nature, 450: 945.

Sumaila, U.R., L. Teh, R. Watson, P. Tyedmers and D. Pauly. 2008. Fuel price increase, subsidies, overcapacity, and resource sustainability. ICES J. Mar. Scien. 65: 832-840.

Ward, M. - 2004. Quantifying the world: UN ideas and statistics. Indiana University Press, Bloomington.

Watson, R. and D. Pauly. - 2001. Systematic distortions in world fisheries catch trends. Nature, 414: 534-536.

Wood, L, L. Fish, J. Laughren and D. Pauly. - 2008. Assessing progress towards global marine protection targets: shortfalls in information and action. Oryx, 42(3): 340-351.

Zeller, D. and D. Pauly. - 2005. Good news, bad news: Global fisheries discards are declining, but so are total catches. Fish Fish., 6: $156-159$.

Zeller, D. and D. Pauly (eds.). - 2007. Reconstruction of Marine Fisheries Catches for Key Countries and Regions (1950-2005). Fish. Centre Res. Rep., 15(2): 1-163.

Scient. ed.: M.P. Olivar.

Received November 24, 2008. Accepted February 20, 2009.

Published online March 2, 2009. 